Check for updates

Cite this: Phys. Chem. Chem. Phys., 2018, 20, 10741

Received 8th November 2017, Accepted 18th January 2018

DOI: $10.1039 / c 7 c p 07552 a$

rsc.li/pccp

\section{$A b$ initio calculations and kinetic modeling of thermal conversion of methyl chloride: implications for gasification of biomass $\dagger$}

\author{
Mallika Singla, ${ }^{a b}$ Morten Lund Rasmussen, ${ }^{a}$ Hamid Hashemi, (D) ${ }^{a}$ Hao Wu, (D) ${ }^{a}$ \\ Peter Glarborg, (DD *a Matteo Pelucchi, (D) ${ }^{c}$ Tiziano Faravellic ${ }^{c}$ and Paul Marshall (D) ${ }^{d}$
}

\begin{abstract}
Limitations in current hot gas cleaning methods for chlorine species from biomass gasification may be a challenge for end use such as gas turbines, engines, and fuel cells, all requiring very low levels of chlorine. During devolatilization of biomass, chlorine is released partly as methyl chloride. In the present work, the thermal conversion of $\mathrm{CH}_{3} \mathrm{Cl}$ under gasification conditions was investigated. A detailed chemical kinetic model for pyrolysis and oxidation of methyl chloride was developed and validated against selected experimental data from the literature. Key reactions of $\mathrm{CH}_{2} \mathrm{Cl}$ with $\mathrm{O}_{2}$ and $\mathrm{C}_{2} \mathrm{H}_{4}$ for which data are scarce were studied by $a b$ initio methods. The model was used to analyze the fate of methyl chloride in gasification processes. The results indicate that $\mathrm{CH}_{3} \mathrm{Cl}$ emissions will be negligible for most gasification technologies, but could be a concern for fluidized bed gasifiers, in particular in lowtemperature gasification. The present work illustrates how ab initio theory and chemical kinetic modeling can help to resolve emission issues for thermal processes in industrial scale.
\end{abstract}

\section{Introduction}

Biomass is considered to be the renewable energy source with the highest potential for meeting the energy needs of the future. ${ }^{1}$ Biomass stores solar energy, which can be utilized in thermal processes such as combustion, gasification and pyrolysis. ${ }^{2}$ It is considered to be a $\mathrm{CO}_{2}$ neutral energy source as the biomass roughly emits the same amount of carbon dioxide during conversion as it takes up during its growth due to photosynthesis. ${ }^{3}$ Biomass gasification aims to convert solid fuels into a combustible gas by using a gasifying agent such as air, oxygen or steam. The quality of the gas produced is dependent on many factors which include the gasifier type, the biomass type, the operating condition and the gasifying agent used. $^{3}$

The gas produced in biomass gasification contains several contaminants such as particulates, tar, alkali metal, sulfur, nitrogen and chlorine, which have to be removed before the

\footnotetext{
${ }^{a}$ DTU Chemical Engineering, Technical University of Denmark, 2800 Lyngby, Denmark.E-mail:pgl@kt.dtu.dk

${ }^{b}$ Department of Biochemical Engineering and Biotechnology,

Indian Institute of Technology Delhi, India

"Dipartimento di Chimica, Materiali e Ingegneria Chimica "G. Natta",

Politecnico di Milano, 20133 Milano, Italy

${ }^{d}$ Department of Chemistry and Center for Advanced Scientific Computing and Modeling, University of North Texas, Denton, Texas, USA

$\dagger$ Electronic supplementary information (ESI) available. See DOI: 10.1039/c7cp07552a
}

gaseous product can be used in gas engines, gas turbines, fuel cells, or synthesis as they may cause problems in the downstream application. ${ }^{4}$ Chlorine levels as low as $20 \mathrm{ppm}$ have been reported to significantly reduce the performance of fuel cells ${ }^{5}$ and it is expected that chlorine levels of less than $0.1 \mathrm{ppm}$ are required to avoid performance loss. ${ }^{6}$ Substantial corrosion of gas turbine blades may also occur at low chlorine concentration $^{5}$ and a tolerance of $0.5 \mathrm{ppm}$ is reported for gas turbines. ${ }^{6}$ Chlorine species are furthermore known to poison catalysts used for conversion of syngas ${ }^{5-7}$ and levels below $1 \mathrm{ppm}$ are desirable. ${ }^{6}$ In addition to this, chlorine species may result in deposition and enhanced corrosion in the downstream processes. ${ }^{6}$

Chlorine is present in biomass mainly in the form of alkali metal salts which vaporize at high temperature within the gasifier and react with water vapor to form hydrogen chloride. ${ }^{5}$ Hydrogen chloride is commonly reported to be the major form of chlorine in the product gases. ${ }^{2,3,5}$ The typical concentration of hydrogen chloride in the produced gas may range from 20 to $200 \mathrm{ppm}$; however, the level may be significantly higher if a biomass with a high chlorine content is used. ${ }^{8}$

Hydrogen chloride is the desired chlorine containing species as it can be removed easily from the fuel gas by a scrubbing process or adsorption on active materials. ${ }^{3,9}$ However, the product gas from a low-temperature circulating fluidized bed gasifier fueled with wheat straw has been reported to contain approximately $100 \mathrm{ppm}$ of methyl chloride, corresponding to $15 \%$ 
of the chlorine present in the fuel. ${ }^{10}$ Methyl chloride may be a direct pyrolysis product from biomass, in particular at lower temperatures, ${ }^{11}$ or may be formed by reaction of $\mathrm{HCl}$ with hydrocarbons under reducing conditions. During pyrolysis at low and moderate heating rates $\left(<1000 \mathrm{~K} \mathrm{~min}^{-1}\right)$ a significant amount of $\mathrm{CH}_{3} \mathrm{Cl}$ is released from $\mathrm{KCl}$-doped pine wood, lignin and pectin. ${ }^{12}$ The formation of $\mathrm{CH}_{3} \mathrm{Cl}$ takes place mainly below $773 \mathrm{~K}$ and can be inhibited by increasing the heating rate of the biomass particles. According to Wang et al. ${ }^{12}$ the methoxy groups in pine wood, lignin and pectin are responsible for the reaction with $\mathrm{KCl}$ leading to formation of $\mathrm{CH}_{3} \mathrm{Cl}$.

Data for methyl chloride emissions from biomass gasification units are very limited, but it is important to assess the magnitude of the problem. The present work aims to evaluate the methyl chloride release from biomass gasification processes. We develop and validate a chemical kinetic model for conversion of $\mathrm{CH}_{3} \mathrm{Cl}$ and use it to assess the fate of this species in the gasifier. The chemistry of chlorinated hydrocarbons has been studied both experimentally and theoretically due to its importance in combustion and in industrial processes. Data on conversion of methyl chloride have been reported from flow reactors, ${ }^{13-16}$ shock tubes, ${ }^{17-20}$ and flames. ${ }^{21-27}$ Previous modeling studies of chlorocarbon conversion ${ }^{13,15,18,25,28-35}$ have mostly relied on rate constants estimated from QRRK theory $^{13,29,31,35}$ or estimation rules. ${ }^{28,36}$ However, significant progress in characterizing key reactions in the $\mathrm{CH}_{3} \mathrm{Cl}$ reaction subset has been made in recent years from theory ${ }^{37,38}$ and measurements. ${ }^{39-44}$ We draw on this work, as well as on ab initio calculations for selected reactions $\left(\mathrm{CH}_{2} \mathrm{Cl}+\mathrm{O}_{2}\right.$ and $\mathrm{CH}_{2} \mathrm{Cl}+\mathrm{C}_{2} \mathrm{H}_{4}$ ) conducted in the present work, to establish a reaction mechanism for $\mathrm{CH}_{3} \mathrm{Cl}$ conversion and validate it by comparison with experimental data. The thermal conversion of $\mathrm{CH}_{3} \mathrm{Cl}$ into other compounds (primarily $\mathrm{HCl}$ ), which are readily separable from the product gas of biomass gasification, is then evaluated from modeling, and the practical implications are discussed.

\section{Chemical kinetic model}

The chemical kinetic model consists of oxidation mechanisms for methane and methyl chloride. The methane mechanism was adopted from the recent work by Hashemi et $a l .{ }^{45}$ The methyl chloride scheme was based on the $\mathrm{HCl} / \mathrm{Cl}_{2}$ subset from Pelucchi et al., ${ }^{46}$ extended in the present work with reactions describing conversion of simple chlorinated hydrocarbons. Where available, rate constants were drawn from experimental work or high-level theory; however, for a number of reactions we have relied on QRRK estimates from Bozzelli and coworkers $^{13,29,31}$ or on estimation rules. ${ }^{28,36}$ The potentially important reactions of $\mathrm{CH}_{2} \mathrm{Cl}$ with $\mathrm{O}_{2}$ and $\mathrm{C}_{2} \mathrm{H}_{4}$, for which data are scarce, were studied by ab initio methods. No parameters in the model were modified to improve agreement with the validation experiments discussed below. The full mechanism, including thermodynamic properties and transport data, is available as ESI. $\dagger$

\section{Theory}

The reactions of the $\mathrm{CH}_{2} \mathrm{Cl}$ radical are important for the oxidation rate of methyl chloride. The reaction with $\mathrm{O}_{2}$ forms an adduct at lower temperatures, ${ }^{42}$ but little is known about the behaviour at higher temperatures. Ho et al. ${ }^{31}$ proposed $\mathrm{CH}_{2} \mathrm{O}+$ $\mathrm{ClO}$ to be the major products and reported a QRRK estimate for the rate constant. However, this estimate is too fast to be consistent with the only experimental determination, consisting of an upper limit of $7.2 \times 10^{7} \mathrm{~cm}^{3} \mathrm{~mol}^{-1} \mathrm{~s}^{-1}$ measured at $800 \mathrm{~K}$ by Shestov et al. $^{44}$

Initial exploration of the potential energy surface (PES) for $\mathrm{CH}_{2} \mathrm{Cl}-\mathrm{O}_{2}$ was carried out using B3LYP/6-311G(2d,d,p) calculations. ${ }^{47}$ We were unable to find a low-barrier path to the $\mathrm{CH}_{2} \mathrm{O}+\mathrm{ClO}$ products. We characterized a peroxy adduct, $\mathrm{CH}_{2} \mathrm{ClOO}$, and a 1,3 hydrogen shift for this adduct leads to $\mathrm{CHClOOH}$ which in turn dissociates readily to $\mathrm{CHClO}+\mathrm{OH}$. This is analogous to the lowest barrier pathway for $\mathrm{CH}_{3}+\mathrm{O}_{2} \cdot{ }^{48}$ Consideration of energies obtained at the CBS-QB3 level ${ }^{47}$ indicates that with a partial pressure of $0.2 \mathrm{~atm}$ of $\mathrm{O}_{2}$, the peroxy adduct is unstable above $c a .750 \mathrm{~K}$ (equilibrium $\left.\left[\mathrm{CH}_{2} \mathrm{ClOO}\right] /\left[\mathrm{CH}_{2} \mathrm{Cl}\right]<1\right)$ and under these conditions the ratelimiting step of the reaction of $\mathrm{CH}_{2} \mathrm{Cl}$ with $\mathrm{O}_{2}$ to yield $\mathrm{CHClO}+$ $\mathrm{OH}$ is the 1,3 hydrogen migration. In order to quantify the kinetics, the geometries and frequencies of the reactants and this transition state (TS, see Fig. 1) were quantified with the M06-2X density functional applied with the MG3 basis set, ${ }^{49}$ followed by single-point energy evaluations using W1BD theory. ${ }^{50}$ All these calculations were carried out with the Gaussian 16 program. ${ }^{51}$ The data were employed in a transition state theory analysis, which included specific allowance for anharmonicity in the umbrella mode of $\mathrm{CH}_{2} \mathrm{Cl}^{52}$ This analysis indicates that $k_{18}$ in Table 1 is smaller than the rate constant for the analogous $\mathrm{CH}_{3}+\mathrm{O}_{2}$ reaction. The results are plotted in

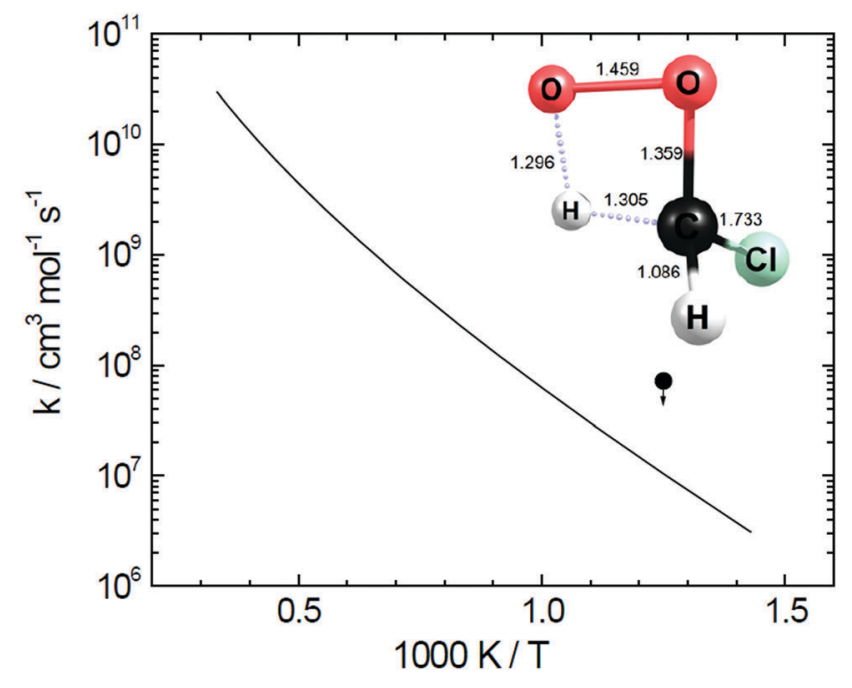

Fig. 1 Transition state theory results for $\mathrm{CH}_{2} \mathrm{Cl}+\mathrm{O}_{2} \rightarrow \mathrm{CHClO}+\mathrm{OH}$ ((R18), solid line) and measured upper limit by Shestov et al. ${ }^{44}$ (filled circle), and the M06-2X/MG3 bond lengths in the transition state for $\mathrm{CH}_{2} \mathrm{ClOO} \rightarrow$ $\mathrm{CHClOOH}$. 
Table 1 Selected reactions in the $\mathrm{CH}_{3} \mathrm{Cl}$ subset. The rate constants are expressed in terms of a modified Arrhenius expression $k=A T^{n} \exp \left(-E_{\mathrm{a}} /(R T)\right)$. The units are $\mathrm{cm}, \mathrm{mol}, \mathrm{s}$ and $\mathrm{cal}$

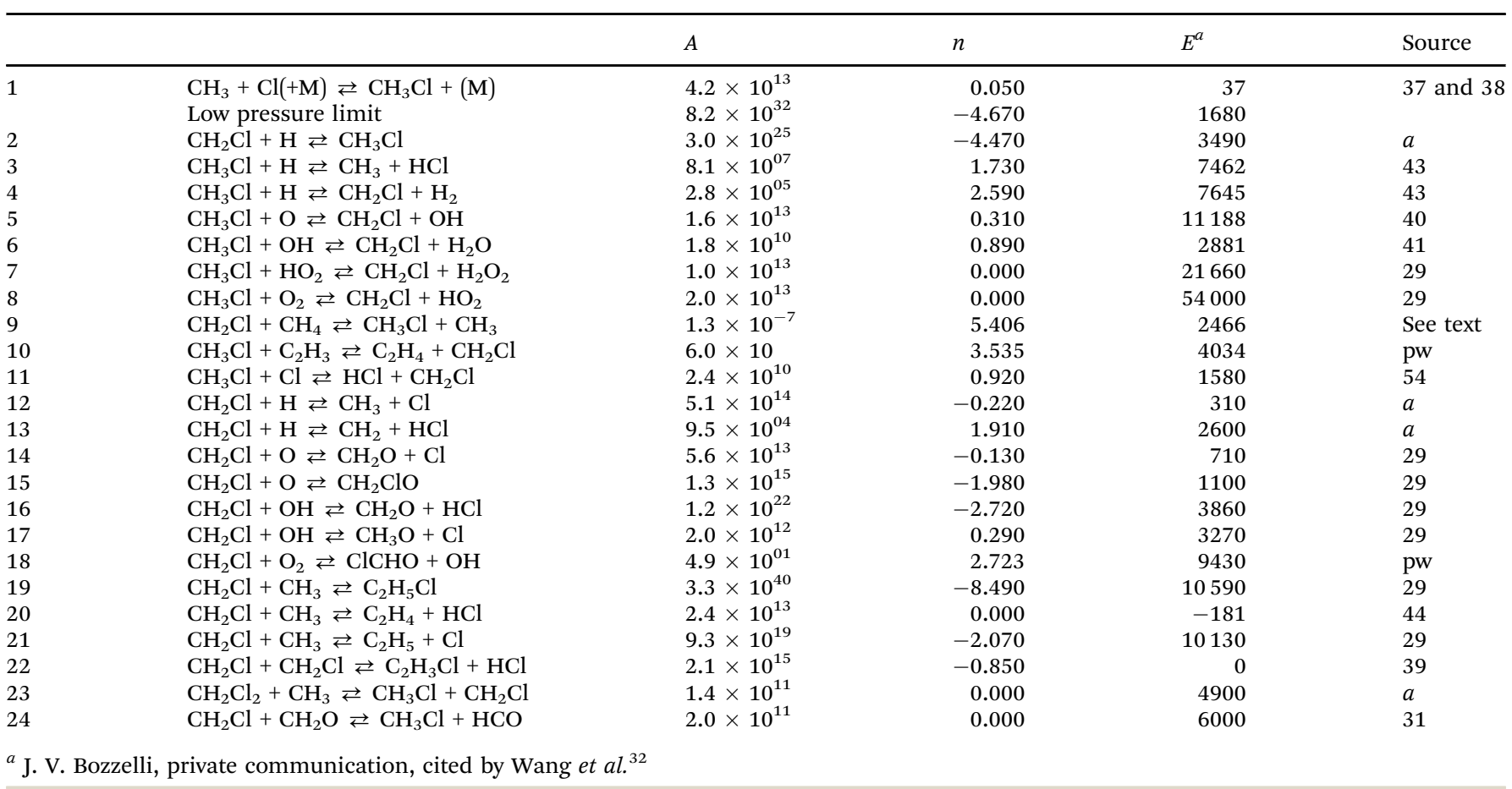

Fig. 1 and are seen to be in accord with the upper limit at $800 \mathrm{~K}$ reported by Shestov et al. ${ }^{44}$

Under gasification conditions, ethylene is present in significant concentrations and the reaction of $\mathrm{CH}_{2} \mathrm{Cl}$ with $\mathrm{C}_{2} \mathrm{H}_{4}$ may become important. However, little is known about the rate constant for this step. We have defined the TS with B3LYP/ 6-311G(2d,d,p) calculations and evaluated the energy barrier with CBS-QB3 theory. ${ }^{47}$ Transition state theory was applied to determine the rate constant $k_{10}$ for $\mathrm{C}_{2} \mathrm{H}_{3}+\mathrm{CH}_{3} \mathrm{Cl} \rightarrow \mathrm{C}_{2} \mathrm{H}_{4}+\mathrm{CH}_{2} \mathrm{Cl}$, with allowance for low-barrier torsion about the $\mathrm{C}-\mathrm{H}-\mathrm{C}$ axis. The results are plotted in Fig. 2. In the reverse direction the rate

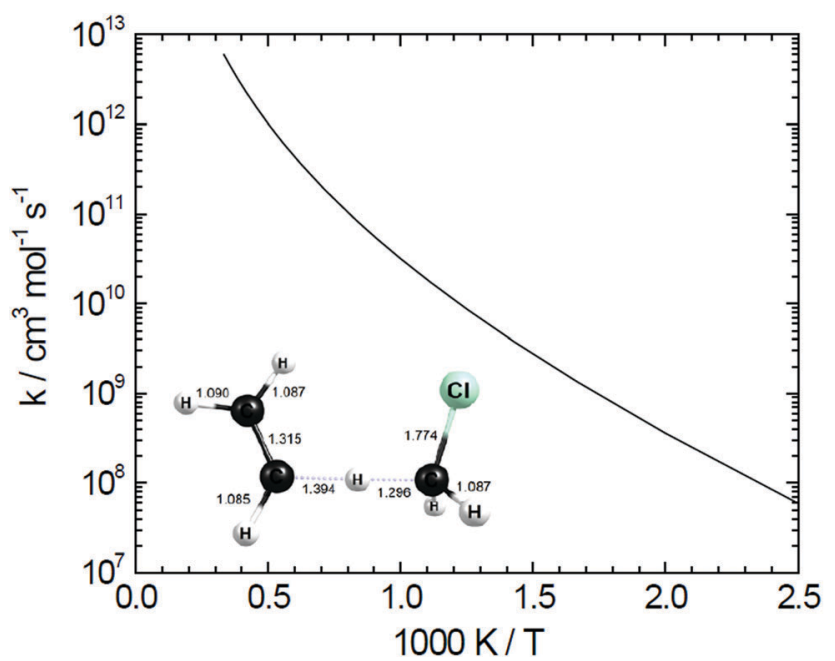

Fig. 2 Transition state theory results for $\mathrm{C}_{2} \mathrm{H}_{3}+\mathrm{CH}_{3} \mathrm{Cl} \rightarrow \mathrm{C}_{2} \mathrm{H}_{4}+\mathrm{CH}_{2} \mathrm{Cl}$ (R10, solid line), and the M06-2X/MG3 bond lengths in the transition state. constant agrees closely (within 20\% over 400-2500 K) with that for the analogous $\mathrm{CH}_{3}+\mathrm{C}_{2} \mathrm{H}_{4}$ reaction.

\section{Reaction mechanism}

Table 1 lists selected reactions important in the thermal conversion of $\mathrm{CH}_{3} \mathrm{Cl}$. Methyl chloride is consumed mainly by thermal dissociation or by reaction with the radical pool. The rate constants for these reactions are generally well established. The thermal dissociation mainly yields $\mathrm{CH}_{3}$ and $\mathrm{Cl}$; we have adopted the rate constant for the reverse step (R1) from the theoretical work of Klippenstein and coworkers. ${ }^{37,38}$ Their value is in good agreement with the experimental data of Abadzhev et $a l .{ }^{55}$ and Lim and Michael. ${ }^{56}$ The reactions of $\mathrm{CH}_{3} \mathrm{Cl}$ with $\mathrm{H}\left((\mathrm{R} 3) \text { and (R4)), }{ }^{43} \mathrm{O}(\mathrm{R} 5),{ }^{40} \text { and } \mathrm{OH} \mathrm{(R6)}\right)^{41}$ are all well characterized experimentally. The most important of these steps under gasification conditions is the reaction $\mathrm{CH}_{3} \mathrm{Cl}+$ $\mathrm{H} \rightleftarrows \mathrm{CH}_{3}+\mathrm{HCl}$ (R3). For this reaction the rate constant is obtained from the combined experimental and theoretical study of Bryukov et al. ${ }^{43}$ For the reaction $\mathrm{CH}_{3} \mathrm{Cl}+\mathrm{CH}_{3} \rightleftarrows$ $\mathrm{CH}_{2} \mathrm{Cl}+\mathrm{CH}_{4}$ (R9b), only the indirect measurements of Macken and Sidebottom ${ }^{53}$ are available. These data were obtained in a narrow temperature range (426-479 K) and extrapolation to higher temperatures is uncertain. We have chosen to include the reaction in the reverse direction, $\mathrm{CH}_{2} \mathrm{Cl}+\mathrm{CH}_{4} \rightleftarrows \mathrm{CH}_{3} \mathrm{Cl}+$ $\mathrm{CH}_{3}$ (R9), assuming the rate constant to be similar to that for $\mathrm{CH}_{3}+\mathrm{CH}_{4} \rightleftarrows \mathrm{CH}_{4}+\mathrm{CH}_{3}$. The Arrhenius plot in Fig. 3 shows that the data from Macken and Sidebottom ${ }^{53}$ for $\mathrm{CH}_{2} \mathrm{Cl}+\mathrm{CH}_{4}$ (reversed through the equilibrium constant) agree well with the rate constant derived theoretically by Ramazani ${ }^{57}$ for the reaction $\mathrm{CH}_{3}+\mathrm{CH}_{4} \rightleftarrows \mathrm{CH}_{4}+\mathrm{CH}_{3}$. Little is known about the 


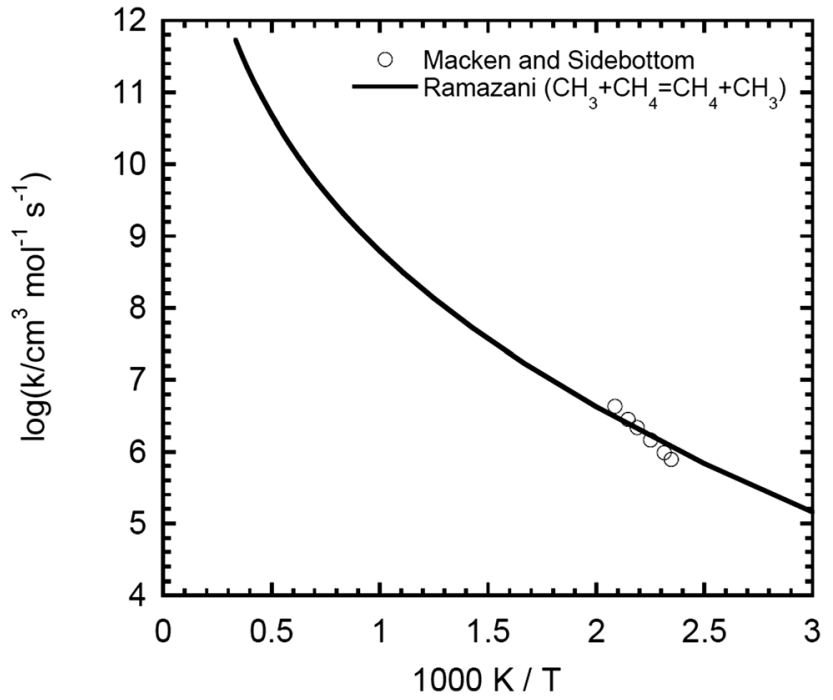

Fig. 3 Arrhenius plot for the reaction $\mathrm{CH}_{2} \mathrm{Cl}+\mathrm{CH}_{4} \rightleftarrows \mathrm{CH}_{3} \mathrm{Cl}+\mathrm{CH}_{3}$ (R9). The symbols denote data derived using the equilibrium constant from measurements of the reverse rate constant $k_{9 b}$ by Macken and Sidebottom. ${ }^{53}$ The solid line is the rate constant derived theoretically by Ramazani ${ }^{57}$ for the reaction $\mathrm{CH}_{3}+\mathrm{CH}_{4} \rightleftarrows \mathrm{CH}_{4}+\mathrm{CH}_{3}$, adopted in the present work for $k_{9}$ (fit to their reported data).

rate constants for reactions of $\mathrm{CH}_{3} \mathrm{Cl}$ with $\mathrm{HO}_{2}$ (R7) and $\mathrm{O}_{2}$ (R8), ${ }^{29}$ but these steps would be expected to be less important under gasification conditions.

Part of the methyl chloride is consumed by hydrogen abstraction reactions to form the $\mathrm{CH}_{2} \mathrm{Cl}$ radical. Similarly to the methyl radical, chloromethyl is not very reactive. Few of the chloromethyl reactions have been studied experimentally and we rely mostly on QRRK estimates from Bozzelli and coworkers. The reactions with the $\mathrm{O} / \mathrm{H}$ radical pool (R12)-(R17) are all expected to be fast. The reaction with $\mathrm{O}_{2}(\mathrm{R} 18)$ is discussed above.

Due to the low reactivity of $\mathrm{CH}_{2} \mathrm{Cl}$, its self-reaction (R22) and reaction with methyl (R19, R20) may become important, in particular under reducing conditions such as in gasification. The rate constant for $\mathrm{CH}_{2} \mathrm{Cl}+\mathrm{CH}_{2} \mathrm{Cl}$ has been measured at low temperature by Roussel et al. ${ }^{39}$ who reported the dominating product channel to be $\mathrm{C}_{2} \mathrm{H}_{3} \mathrm{Cl}+\mathrm{HCl}$ (R21). The overall rate constant for the $\mathrm{CH}_{2} \mathrm{Cl}+\mathrm{CH}_{3}$ reaction was measured in the 300-800 K range by Shestov et al. ${ }^{44}$ they reported formation of $\mathrm{C}_{2} \mathrm{H}_{4}$ but did not detect $\mathrm{C}_{2} \mathrm{H}_{5}$ or $\mathrm{C}_{2} \mathrm{H}_{5} \mathrm{Cl}$, so we assume $\mathrm{C}_{2} \mathrm{H}_{4}+\mathrm{HCl}$ (R19) to be the main products.

The reaction mechanism also includes subsets for oxidation of $\mathrm{CH}_{2} \mathrm{Cl}_{2}, \mathrm{C}_{2} \mathrm{H}_{5} \mathrm{Cl}$, and $\mathrm{C}_{2} \mathrm{H}_{3} \mathrm{Cl}$. These species are mostly formed from recombination steps, such as $\mathrm{CH}_{2} \mathrm{Cl}+\mathrm{Cl} \rightleftarrows \mathrm{CH}_{2} \mathrm{Cl}_{2}, \mathrm{CH}_{2} \mathrm{Cl}+$ $\mathrm{CH}_{3} \rightleftarrows \mathrm{C}_{2} \mathrm{H}_{5} \mathrm{Cl}$, and $\mathrm{CH}_{2} \mathrm{Cl}+\mathrm{CH}_{2} \mathrm{Cl} \rightleftarrows \mathrm{C}_{2} \mathrm{H}_{3} \mathrm{Cl}+\mathrm{HCl}(\mathrm{R} 22)$. Under gasification conditions, formation of higher chlorinated hydrocarbons and di-chlorocarbons is insignificant due to the low concentrations of chlorine species, but they play a role under the conditions of some of the validation experiments discussed below.

\section{Numerical approach}

The modeling is performed with the software packages Chemkin ${ }^{58}$ and OpenSMOKE, ${ }^{59}$ respectively. A quantitative mechanism consists of a list of the dozens or hundreds of individual chemical species to be considered, both stable molecules and radical intermediates, and the hundreds or thousands of elementary chemical reactions which interconvert these species. As discussed above, individual rate constants for the most important processes ideally originate from direct measurement of isolated elementary reaction kinetics or from high-level quantum chemical analysis of transition states but, because of the large amount of information needed, must also include data from empirical estimation schemes and analogies with known systems. For each species the formation and consumption kinetics can be summed, leading to a set of coupled differential equations for the concentration which can be solved numerically to obtain the time-history for each species. A challenge is that these are "stiff" equations, reflecting that the time scales for different chemical reactions span many orders of magnitude. Strategies for solution of such differential equations have been discussed elsewhere ${ }^{60}$ and popular codes to accomplish this include Chemkin and OpenSMOKE. ${ }^{58,59}$ The program documentation should be consulted for details of these applications.

For each species thermodynamic information (the enthalpy of formation, entropy, heat capacity and their temperature dependence) is incorporated via polynomial fits in NASA format. ${ }^{61}$ This enables detailed balance, the idea that the ratio of forward and reverse rate constants equals the equilibrium constant, to be maintained in the overall kinetic analysis. The practical systems considered here are, to a good approximation, constant-pressure, homogenous and isothermal systems, which means that the concentrations of target species are only dependent on details of the chemistry outlined below. For nonhomogeneous systems such as premixed flames, diffusion is accounted for using information about transport properties, and temperature profiles may be imposed. Temperature variation, such as in a flame, may also be deduced from the chemical heat release.

\section{Validation of the model}

The chemical kinetic model here presented has been evaluated against selected experimental data from flow reactors, shock tubes, and flames. As it was not the aim to conduct a comprehensive validation, we selected data obtained under conditions relevant for gasification. However, results obtained under conditions directly resembling those of gasification, i.e., at reducing conditions with low levels of $\mathrm{O}_{2}$ or at $\mathrm{O}_{2}$-free conditions with significant amounts of $\mathrm{H}_{2} \mathrm{O}$ and/or $\mathrm{CO}_{2}$ are limited. The validation covers data obtained in the absence of oxygen (flow reactor data $\left.{ }^{14,16}\right)$ and data obtained in an oxidizing atmosphere (flow reactor data, ${ }^{13}$ shock tube ignition delays, ${ }^{17,18}$ and flame speeds $^{22,24}$ ), respectively.

\section{Pyrolysis conditions}

Hung et $a{ }^{14}{ }^{14}$ studied the thermal decomposition of methyl chloride in nitrogen. The study was performed in an isothermal flow reactor at temperatures in the range 1000-1350 K. Fig. 4 compares the experimental data with modeling predictions. The model captures well the decomposition of $\mathrm{CH}_{3} \mathrm{Cl}$, the formation 

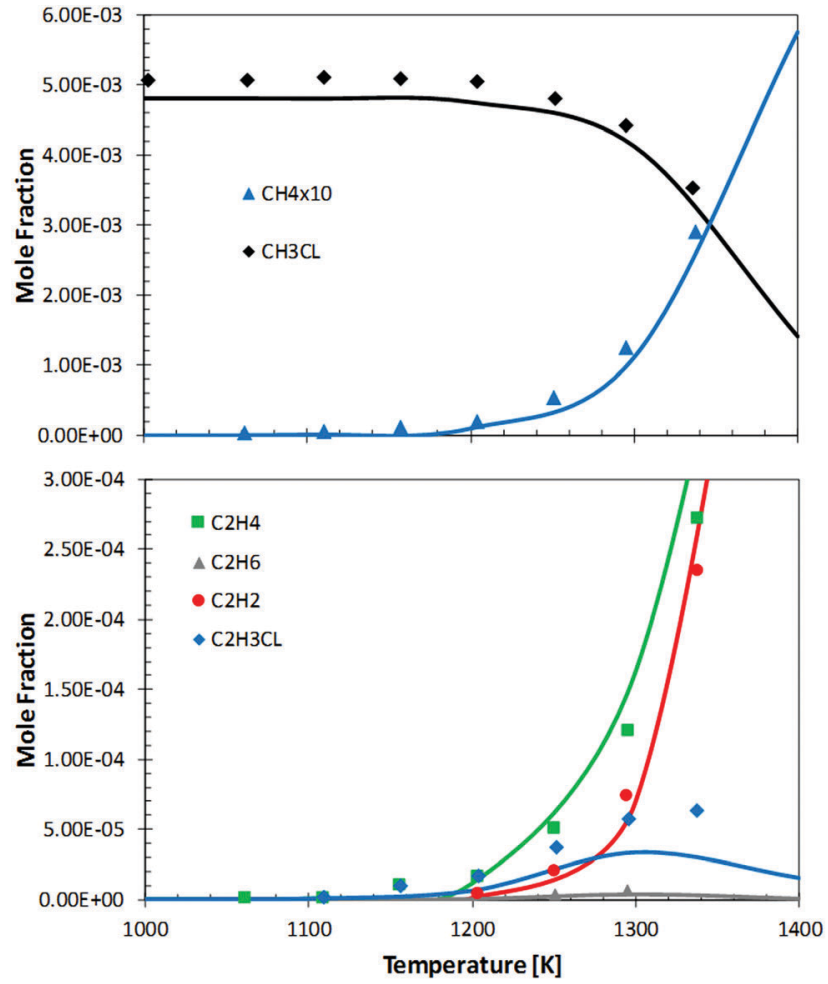

Fig. 4 Comparison of model predictions (lines) and experimental data (symbols) for thermal decomposition of methyl chloride (4800 ppm) in a nitrogen atmosphere plotted as a function of temperature. The pressure was $1.14 \mathrm{~atm}$ within the reactor and the residence time is calculated as $\tau(\mathrm{s})=21510 / T$. The experimental results are from Hung et al. ${ }^{14}$

of $\mathrm{CH}_{4}$, which is a major product, and the minor products $\mathrm{C}_{2} \mathrm{H}_{3} \mathrm{Cl}$, $\mathrm{C}_{2} \mathrm{H}_{4}$ and $\mathrm{C}_{2} \mathrm{H}_{2}$.

$\mathrm{Wu}$ and $\mathrm{Won}^{16}$ studied the thermal decomposition of methyl chloride in a hydrogen atmosphere in an isothermal flow reactor at atmospheric pressure. Data obtained at $1123 \mathrm{~K}$ are compared with model predictions in Fig. 5 . The predictions show good agreement with the experimental data for methyl chloride and methane. However, the model overpredicts the concentration of hydrogen chloride and underpredicts the formation of ethane and ethylene. The discrepancy observed for $\mathrm{HCl}$ may partly be attributed to difficulties in measuring the concentration of hydrogen chloride as it may adsorb on the walls of the reactor and the outlet. In fact, the chlorine balance for the experimental data does not add up.

In Fig. 6, model predictions are compared with the experimental data from $\mathrm{Wu}$ and $\mathrm{Won}^{16}$ for $\mathrm{CH}_{3} \mathrm{Cl}+\mathrm{H}_{2}$ as a function of temperature for a fixed residence time of one second. In general the agreement between the predictions and the experimental data is satisfactory. However, the predicted decomposition of methyl chloride is slightly too fast, resulting in an overprediction of the concentrations of methane and hydrogen chloride below $1073 \mathrm{~K}$. The levels of the minor products ethylene and ethane are underpredicted in the entire temperature interval.

Under both inert conditions (Fig. 4) and in hydrogen (Fig. 5 and 6), the prediction of methyl chloride is mostly sensitive to
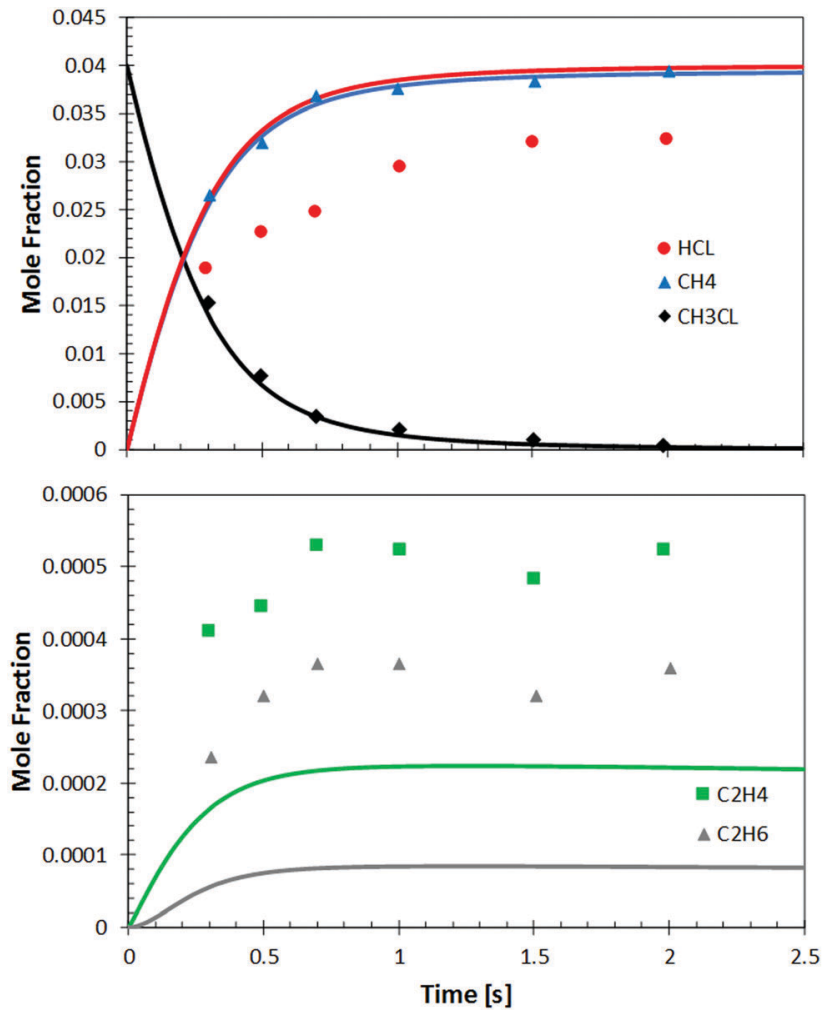

Fig. 5 Comparison of experimental data (symbols) and model predictions (lines) for the thermal decomposition of methyl chloride (4\%) in a hydrogen atmosphere $(96 \%)$ plotted as a function of residence time. The experiment was conducted at atmospheric pressure and at a temperature of $1123 \mathrm{~K}$. The experimental results are from $\mathrm{Wu}$ and Won. ${ }^{16}$

the unimolecular decomposition of methyl chloride (R1). However, in excess of hydrogen, the $\mathrm{CH}_{3} \mathrm{Cl}$ consumption rate also becomes sensitive to reaction (R3), $\mathrm{CH}_{3} \mathrm{Cl}+\mathrm{H} \rightleftarrows \mathrm{CH}_{3}+\mathrm{HCl}$.

\section{Oxidative conditions}

Ho et $a .^{13}$ studied the oxidation of methyl chloride in hydrogen/ oxygen/argon mixtures in a flow reactor in the temperature range 1098-1223 K. In Fig. 7 the predicted and measured profiles of methyl chloride are depicted. In general, the agreement is satisfactory, even though the model tends to underpredict the consumption rate for $\mathrm{CH}_{3} \mathrm{Cl}$ at the higher temperatures. Bozzelli et al. also measured the concentration of selected products; these data are compared with modeling predictions in Fig. 8 for a temperature of $1173 \mathrm{~K}$. Again, the agreement between the model and the experimental data is satisfactory, even though the consumption of $\mathrm{CH}_{3} \mathrm{Cl}$ is slightly underpredicted by the model.

The reaction mechanism was validated against ignition delays for methyl chloride. Miller et al. ${ }^{17}$ reported data for methyl chloride, methane, and a methyl chloride/hydrogen mixture at a pressure of $2 \mathrm{~atm}$ and temperatures of 1300-1600 K. They defined the ignition delay time as the interval between the arrival of the shock and a sudden increase in temperature due to the onset of exothermic reactions. The ignition delay is thus simulated as the time where the slope of the temperature profile reaches its maximum value. The predicted and experimental ignition delays 

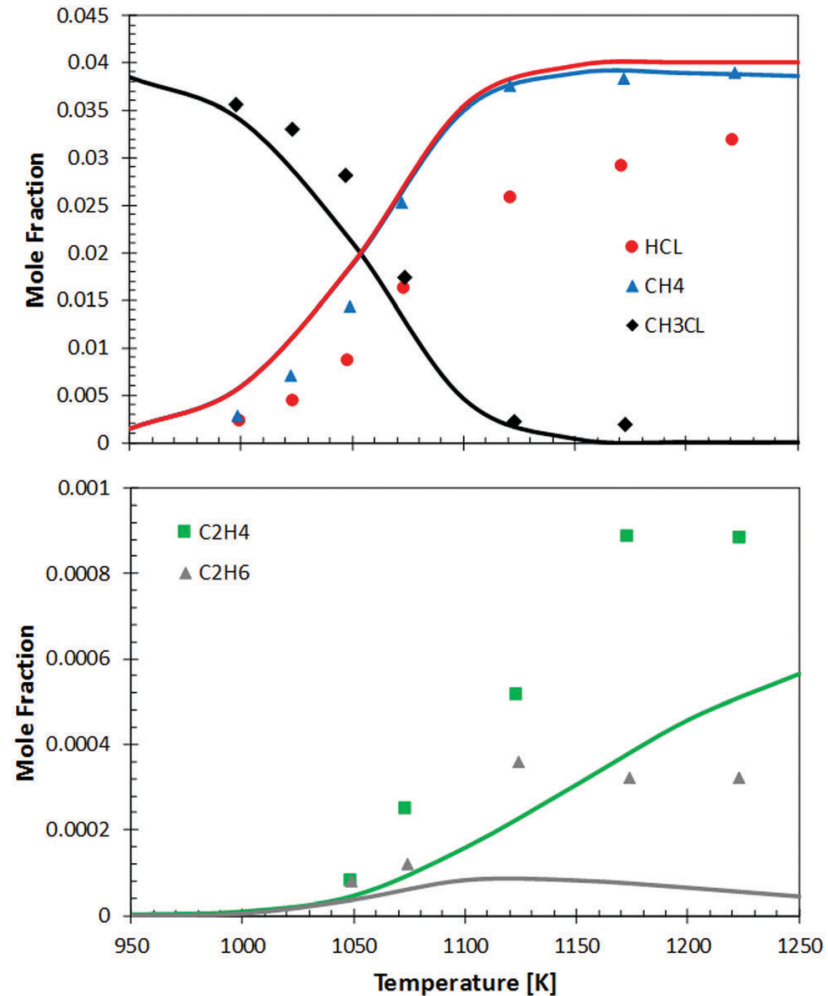

Fig. 6 Comparison of experimental data (symbols) and model predictions (lines) for the thermal decomposition of methyl chloride (4\%) in a hydrogen atmosphere (96\%) plotted as a function of temperature for a fixed residence time of 1 second. The experiments were conducted at atmospheric pressure. The experimental results are from Wu and Won. ${ }^{16}$

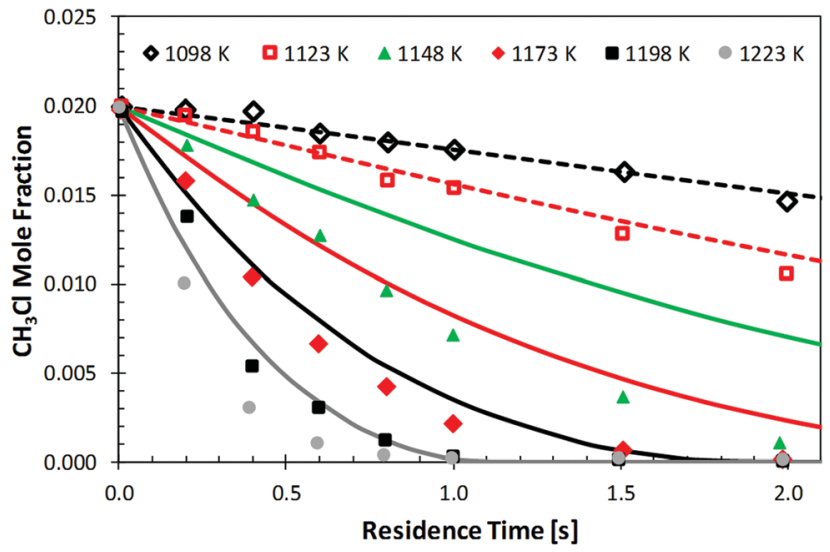

Fig. 7 Comparison of experimental data (symbols) and model prediction (lines) for oxidation of methyl chloride in $\mathrm{H}_{2} / \mathrm{O}_{2} / \mathrm{Ar}$ mixtures at different temperatures. The initial concentrations were $1 \% \mathrm{H}_{2}, 1 \% \mathrm{O}_{2}, 2 \% \mathrm{CH}_{3} \mathrm{Cl}$ and $96 \% \mathrm{Ar}$. The experiments were conducted at $1 \mathrm{~atm}$ and the experimental results are from Ho et al. ${ }^{13}$

are compared in Fig. 9. The best agreement is seen for methane, while the ignition delay times for methyl chloride and for the mixture of methyl chloride and hydrogen are overpredicted, mainly at lower temperatures.

The predictions for $\mathrm{CH}_{3} \mathrm{Cl}$ are very sensitive to its unimolecular decomposition (R1), as well as to the reactions of
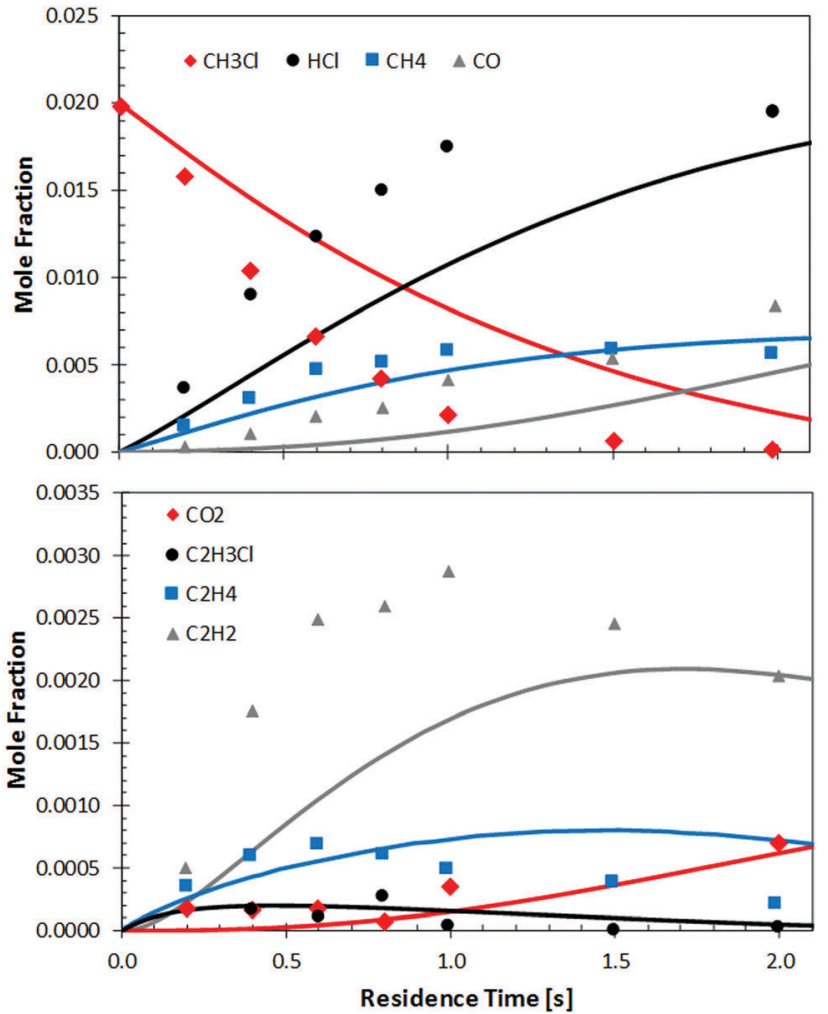

Fig. 8 Comparison of experimental data (symbols) and model prediction (lines) for the oxidation of methyl chloride in a $\mathrm{H}_{2} / \mathrm{O}_{2} / \mathrm{Ar}$ mixture plotted as a function of residence time for a fixed temperature of $1173 \mathrm{~K}$. The initial concentrations were $1 \% \mathrm{H}_{2}, 1 \% \mathrm{O}_{2}, 2 \% \mathrm{CH}_{3} \mathrm{Cl}$ and $96 \%$ Ar. The experiments were conducted at $1 \mathrm{~atm}$ and the experimental results are from Ho et al. ${ }^{13}$

$\mathrm{CH}_{2} \mathrm{Cl}$ with $\mathrm{O}_{2}$ (R18) and with $\mathrm{CH}_{2} \mathrm{Cl}(\mathrm{R} 22)$. The value of $k_{1}$ has been validated over a wide range of conditions by Klippenstein and coworkers ${ }^{37,38}$ and is therefore thought to be reliable. We also trust that the rate constants for the reaction of $\mathrm{CH}_{2} \mathrm{Cl}$ with $\mathrm{O}_{2}$ and the $\mathrm{CH}_{2} \mathrm{Cl}$ self-reaction are fairly accurate, but the subsequent reactions of chlorinated $\mathrm{C}_{2}$-hydrocarbons involve somewhat larger uncertainties.

Finally, predictions for the burning velocity of pure methyl chloride-air flames are compared with the experimental data of Kaesche-Krischer ${ }^{62}$ and Chelliah et al. ${ }^{24}$ in Fig. 10. There is a significant difference between the experimental data obtained by the two groups; however, the results show the same trend and the peak occurs at about the same equivalence ratio. The model underpredicts the burning velocity when compared to the data by Chelliah et al., which would be expected to be more reliable than the early results from Kaesche-Krischer. Under fuel-lean conditions the predictions are sensitive to reactions involving chloromethyl while they are more sensitive to the reactions $\mathrm{H}+\mathrm{O}_{2} \rightleftarrows \mathrm{O}+\mathrm{OH}$ and $\mathrm{HCO}(+\mathrm{M}) \rightleftarrows \mathrm{H}+\mathrm{CO}(+\mathrm{M})$ under fuel-rich conditions.

Model predictions for burning velocities of fuels containing equal amounts of methyl chloride and methane are compared with experimental data by Valeiras et $a .^{22}$ and Chelliah et al. ${ }^{24}$ in Fig. 11. Again, there is significant scatter in the experimental 


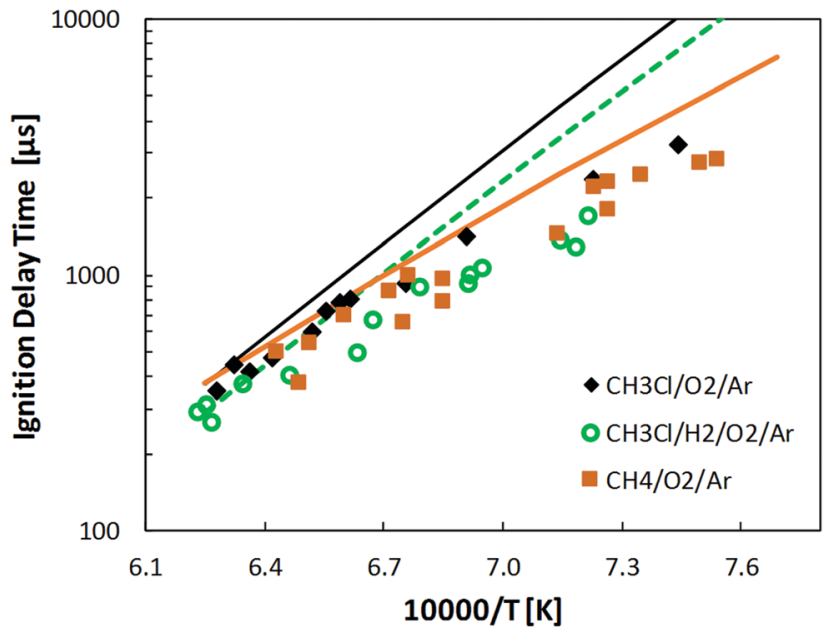

Fig. 9 Ignition delay times for $\mathrm{CH}_{3} \mathrm{Cl}, \mathrm{CH}_{4}$, and a $\mathrm{CH}_{3} \mathrm{Cl} / \mathrm{H}_{2}$ mixture Symbols mark experimental results from Miller et al. ${ }^{17}$ and lines denotes the prediction of the present model. The pressure behind the reflected shock was $2 \mathrm{~atm}$. Inlet compositions: $10 \% \mathrm{CH}_{3} \mathrm{Cl}$ and $15 \% \mathrm{O}_{2}$ (mixture 1); $10 \% \mathrm{CH}_{4}, 15 \% \mathrm{O}_{2}$ (mixture 2); $10 \% \mathrm{CH}_{3} \mathrm{Cl}, 1 \% \mathrm{H}_{2}, 15 \% \mathrm{O}_{2}$ (mixture 3); balance $\mathrm{Ar}$

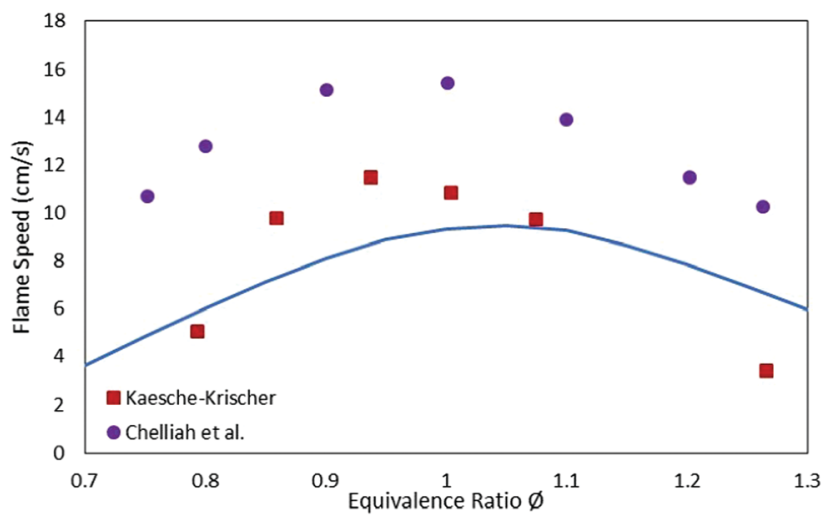

Fig. 10 Laminar burning velocities of methyl chloride-air mixtures as a function of fuel-air equivalence ratio. The squares are experimental results from Kaesche-Krischer ${ }^{62}$ while the circles are from Chelliah et al. ${ }^{24}$ The line denotes the model predictions. The initial temperature was $298 \mathrm{~K}$ while the pressure was $1 \mathrm{~atm}$.

data. The model predictions fall roughly in between the results of Chelliah et al. and Valeiras et al.

The prediction of the burning velocity for methyl chloride/ methane mixtures is mostly sensitive to the reactions belonging to the methane subset, while reactions involving chlorinated species are less important, in particular under reducing conditions. This finding is in agreement with the observations of Wang et al. ${ }^{32}$ As it is typically observed for flame speed predictions, the chain branching reaction $\mathrm{H}+\mathrm{O}_{2} \rightleftarrows \mathrm{O}+\mathrm{OH}$ is found to be the most important reaction. The dissociation of HCO promotes the burning velocity whereas its reactions with $\mathrm{Cl}$ and $\mathrm{O}_{2}$ slow down the oxidation as these steps terminate the radical chain. Also the terminating recombination reaction $\mathrm{CH}_{3}+\mathrm{Cl}(+\mathrm{M})$ (R1b) serves to reduce the burning velocity.

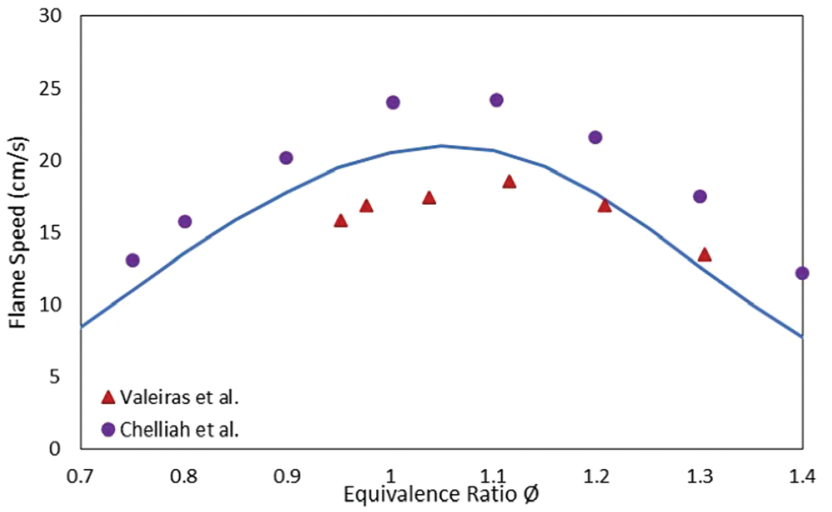

Fig. 11 Laminar burning velocity of fuel mixtures of $50 \% \mathrm{CH}_{3} \mathrm{Cl}$ and $50 \%$ $\mathrm{CH}_{4}$ in air as a function of fuel-air equivalence ratio. The experimental results are from Valeiras et al. ${ }^{22}$ and Chelliah et al. ${ }^{24}$ The initial temperature was $293-298 \mathrm{~K}$ while the pressure was $1 \mathrm{~atm}$. The predictions were made for a temperature of $298 \mathrm{~K}$.

\section{Implications for biomass gasification}

In the previous section it was shown that the chemical kinetic model provides a satisfactory description of conversion of methyl chloride under both pyrolysis and oxidative conditions. The major differences between predictions and experimental results were seen in the presence of significant amounts of oxygen; conditions that are less relevant for gasification. Based on the validation, we believe that the model is sufficiently reliable to be used to asses the fate of $\mathrm{CH}_{3} \mathrm{Cl}$ in biomass gasification processes.

In this section, we conduct simulations for each of the most common gasification technologies, i.e., bubbling and circulating fluidized beds, downdraft gasifiers, and entrained-flow gasifiers. Characteristics of these technologies can be found elsewhere. ${ }^{63}$ Data reported on the gas composition within gasifiers as a function of the operating conditions are very limited. ${ }^{64,65}$ For this reason we assume in the calculations that the inlet gas composition is similar to that of the exit gas composition reported for the specific type of gasifier. For each gasification technology, the exit gas composition from several studies have been considered. The gas compositions reported in literature vary a lot, even for the same gasification technology and gasifying agent. An average composition has been used in the modeling.

The major components in the exit gas are $\mathrm{H}_{2}, \mathrm{CO}, \mathrm{CO}_{2}, \mathrm{CH}_{4}$, $\mathrm{C}_{2} \mathrm{H}_{4}, \mathrm{H}_{2} \mathrm{O}$, and $\mathrm{N}_{2}$. The methyl chloride content of the gas has only been reported for a product gas from a low-temperature circulating fluidized bed gasifier. ${ }^{10}$ We adopt this value (100 ppm) to be representative in our calculations. The concentration of methyl chloride may, however, be significantly lower for gasifiers using biomass with a low chlorine content such as woody biomass. Furthermore, the formation of methyl chloride is temperature dependent ${ }^{66}$ so the yield may vary greatly, dependent on the operating temperature of the gasifier.

For all gasification technologies it is assumed that the gas flow can be approximated as plug flow throughout the gasifier. The decomposition of methyl chloride is assumed to 
be kinetically controlled and mixing limitations are thereby neglected in the modeling. Finally, it is assumed that the zone in which the thermal conversion of methyl chloride occurs is isothermal. The applicability of these assumptions is discussed below for each gasification technology.

\section{Circulating fluidized bed (CFB)}

Kersten et al. ${ }^{67}$ reported that the majority of the pyrolysis took place within the first 1.5 meter of their 6 meter high circulating fluidized bed gasifier. The combustion zone was located within the first 0.7 meters of the gasifier; they never detected oxygen at their lowest sampling point, which was located 0.7 meters above the air nozzles. Based on their results, we assume that the drying, pyrolysis and combustion processes occur at the bottom of the gasifier while the thermal conversion of methyl chloride occurs in the dilute zone, assumed to be oxygen-free. Based on reported gas velocities, ${ }^{67,68}$ we estimate the residence time within the dilute zone to be of the order of $0.5-2.0 \mathrm{~s}$.

In Table 2, the exit gas composition and the operating temperatures for several CFB biomass gasifiers are listed. The averaged gas composition reported in the table is assumed to be representative for CFB gasifiers. Our calculations indicate that the concentration of the major species remains largely constant in the dilute zone, even though some of the ethylene is decomposed into hydrogen and acetylene at high operating temperatures.

In the CFB gasifier, the axial temperature gradient in the riser is small; it has been reported to be between 30 and $50 \mathrm{~K}$ from the top to the bottom. ${ }^{10,67}$ It is thus reasonable to model the CFB gasifier as isothermal. The assumption about plug flow is less accurate. In a CFB the solid biomass tend to migrate towards the wall, causing more gas to be produced near the wall. Due to this, parabolic radial gas profiles appear within the gasifier.

The predictions for the thermal conversion of methyl chloride within a CFB are shown in Fig. 12. Simulations have been performed as a function of temperature within the range reported in Table 2. It can be seen that the thermal conversion of methyl chloride is very sensitive to the temperature. At very low temperatures (923-973 K), conversion of methyl chloride is low. Consequently, most of the methyl chloride exiting the combustion zone for gasifiers operating at low temperatures appears in the exit gas. The prediction is consistent with the

Table 2 Exit gas composition from CFB biomass gasifiers. The gas composition is given on a dry basis in vol\% (balance $\mathrm{N}_{2}$ )

\begin{tabular}{llllllll}
\hline $\mathrm{H}_{2}$ & $\mathrm{CO}$ & $\mathrm{CO}_{2}$ & $\mathrm{CH}_{4}$ & $\mathrm{C}_{2} \mathrm{H}_{4}$ & $\mathrm{H}_{2} \mathrm{O}$ & Temperature [K] & Source \\
\hline 12 & 14 & 16 & 4.0 & 1.5 & 12 & $1023-1173$ & 67 \\
5.4 & 8.6 & 22 & 5.4 & 1.6 & - & $1023-1053$ & 68 \\
16 & 18 & 16 & 5.5 & 1.7 & 13 & 1123 & 69 \\
9 & 13 & 15 & 8.5 & - & 12 & $973-1223$ & 70 \\
9 & 13 & 15 & 8.5 & - & 12 & $1123-1173$ & 70 \\
$15-17$ & $21-22$ & $10-11$ & $5-6$ & - & - & 1173 & 70 \\
9.5 & 9.7 & 17 & 7.2 & - & - & - & 71 \\
$9.5-12$ & $16-19$ & $14-18$ & $5.8-7.5$ & - & - & - & 71 \\
11 & 14 & 16 & 6.2 & 1.6 & 12 & & Average
\end{tabular}

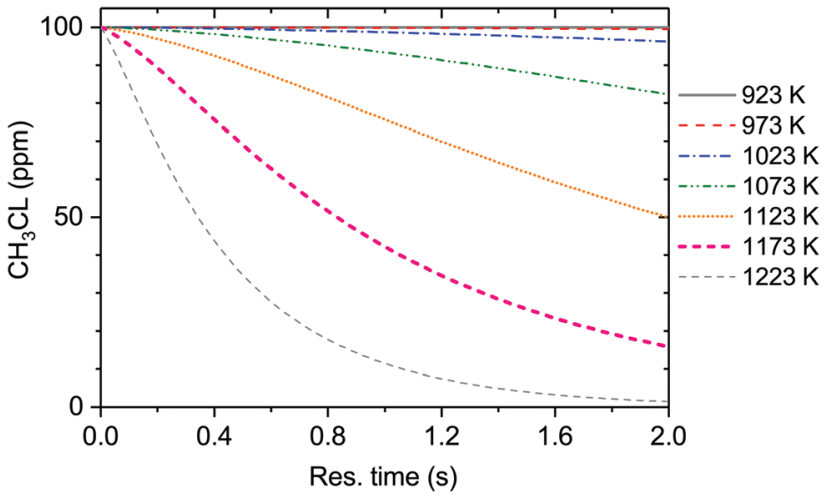

Fig. 12 Thermal conversion of methyl chloride within a CFB gasifier. The initial gas composition for the simulation is $11 \% \mathrm{H}_{2}, 14 \% \mathrm{CO}, 16 \% \mathrm{CO}_{2}, 6.2 \%$ $\mathrm{CH}_{4}, 1.6 \% \mathrm{C}_{2} \mathrm{H}_{4}, 12 \% \mathrm{H}_{2} \mathrm{O}$; balance $\mathrm{N}_{2}$ (see Table 2). The pressure is atmospheric; temperature and residence time as shown in the figure.

measured levels of methyl chloride in the exit gas from a lowtemperature gasifier. ${ }^{10}$

At temperatures above $973 \mathrm{~K}$, the conversion of methyl chloride increases. However, even at the highest temperature of $1223 \mathrm{~K}$ methyl chloride is not depleted within one second. The calculations indicate that methyl chloride formed within a CFB gasifier may appear in the exit gas.

The gas-phase conversion of methyl chloride under CFB gasification conditions is shown in Fig. 13. Methyl chloride is mainly consumed by thermal dissociation (R1) and by reaction with atomic hydrogen ((R3) and (R4)). The majority of the methyl chloride is converted by reaction (R3), forming methyl radicals and hydrogen chloride. As the temperature increases, a larger fraction of the methyl chloride is converted by thermal dissociation (R1). The majority of the formed methyl radicals react with water, molecular hydrogen or atomic hydrogen to form methane. A part of the methyl chloride is converted by the reaction $\mathrm{CH}_{3} \mathrm{Cl}+\mathrm{H} \rightleftarrows \mathrm{CH}_{2} \mathrm{Cl}+\mathrm{H}_{2}$ (R4), which forms chloromethyl. The chloromethyl radicals mainly react with atomic hydrogen to form chlorine atoms (R12) or with methyl radicals to form $\mathrm{HCl}(\mathrm{R} 20)$. A minor fraction of $\mathrm{CH}_{2} \mathrm{Cl}$ is converted back into methyl chloride by reaction with ethylene (R10b). The atomic chlorine, formed from decomposition of

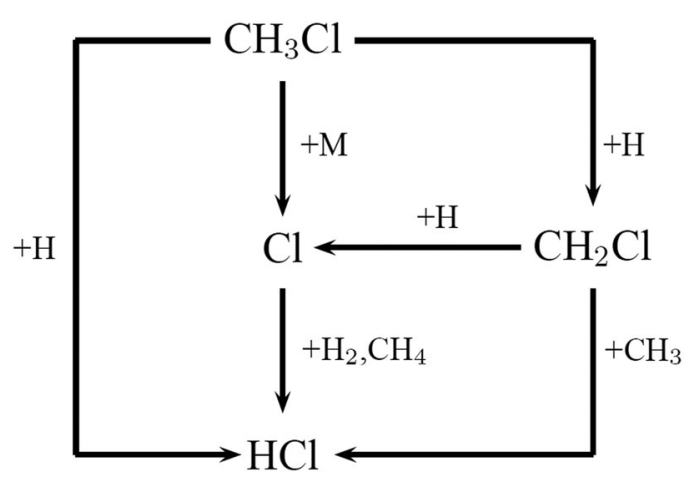

Fig. 13 Reaction pathway for the methyl chloride consumption under gasification conditions in a circulating fluidized bed reactor. 
methyl chloride (R1) and the reaction of chloromethyl with atomic hydrogen (R12), reacts with molecular hydrogen, methane, or, to a lower extent, ethylene to form hydrogen chloride. Overall, the methyl chloride consumed is largely converted into hydrogen chloride.

The reaction pathways for methyl chloride under gasification conditions have similarities with those occurring in a hydrogen atmosphere (see previous section). However, under gasification conditions the prediction of methyl chloride is less sensitive to the reactions with chloromethyl. This is because methyl chloride is not a major component in the gas under gasification conditions, as it was in the validation experiments. Due to this, chloromethyl is formed only in trace amounts under gasification conditions and the reactions consuming chloromethyl radicals are less important for terminating or propagating the radical chain.

\section{Bubbling fluidized bed (BFB)}

In the bubbling fluidized bed it is assumed that the drying, pyrolysis and combustion occur in the bed, while the thermal conversion of methyl chloride takes place in the free-board. Ross et al. ${ }^{65}$ studied the axial gas profiles in a $2.7 \mathrm{~m}$ high BFB biomass gasifier and detected no oxygen beyond their second sampling point which was located $12 \mathrm{~cm}$ above the air distributor plate. Consequently, we assume in this work that all oxygen is rapidly consumed in the bed and that the thermal conversion of methyl chloride proceeds in the absence of oxygen.

In Table 3, the exit gas composition and the operating temperatures for several BFB biomass gasifiers are listed. Again, the average gas composition is assumed to be representative for the gasifier. By comparing Tables 2 and 3 it can be seen that the BFB and CFB reactors operate within the same temperature range and that the exit gas composition of the two gasifiers is similar.

In the free-board of a BFB, plug flow provides a reasonably good description of the gas flow. ${ }^{75}$ For BFB there is a high degree of temperature uniformity within the bed while the gas temperature decreases within the free-board due to the endothermic gasification reactions taking place. Bridgewater ${ }^{72}$ reports the temperature drop in the freeboard to be around $50 \mathrm{~K}$ for typical BFB gasifiers, but depending on the operating conditions and design of the gasifier, values as high as $150-200 \mathrm{~K}$ have been reported. ${ }^{76,77}$ The assumption of isothermal conditions

Table 3 Exit gas composition from BFB biomass gasifiers. The gas composition is given on a dry basis in vol\% (balance $\mathrm{N}_{2}$ ). The water content was estimated to be $26 \%$

\begin{tabular}{llllllll}
\hline $\mathrm{H}_{2}$ & $\mathrm{CO}$ & $\mathrm{CO}_{2}$ & $\mathrm{CH}_{4}$ & $\mathrm{C}_{2} \mathrm{H}_{4}$ & $\mathrm{H}_{2} \mathrm{O}$ & Temperature $[\mathrm{K}]$ & Source \\
\hline 9 & 14 & 20 & 7 & - & - & 850 & 72 \\
$5-16$ & $10-22$ & $9-19$ & $2-6$ & $0.2-3.3$ & $11-34$ & $1053-1103$ & 73 \\
5.8 & 18 & 16 & 4.6 & 2.6 & - & 923 & 70 \\
14 & 16 & 16 & 5.8 & - & 18 & $1123-1223$ & 70 \\
4.1 & 24 & 13 & 3.1 & - & - & 1003 & 70 \\
13 & 16 & 16 & 5.7 & - & - & $923-1098$ & 70 \\
$8-12$ & $10-14$ & $17-20$ & $5-7$ & - & - & $973-1093$ & 74 \\
9.4 & 17 & 16 & 5.2 & 2.2 & 20 & & Average
\end{tabular}

within the free-board may therefore be inaccurate for some BFB gasifiers.

Since the gas composition and temperatures of a BFB gasifier are similar to those of a CFB gasifier, the rate at which the decomposition of methyl chloride occurs within the BFB is also similar to that for a CFB. However, with gas residence times in the freeboard in the range $2-4 \mathrm{~s},{ }^{65,74,78}$ the time for reaction in a BFB is longer than that of a CFB. According to calculations, this is sufficient to obtain full conversion of methyl chloride at the higher temperatures. However, as most BFB gasifiers operate in the $1060-1140 \mathrm{~K}$ range, ${ }^{71}$ presence of methyl chloride in the exit gas stream should be a concern.

\section{Downdraft gasifier}

In the downdraft gasifier the pyrolysis and thereby the formation of methyl chloride occurs just above combustion zone. Due to this, the decomposition of methyl chloride will mainly occur in the combustion zone. The temperature within this region has been reported to fluctuate in the range 1073$1473 \mathrm{~K}^{64,71,79}$ for downdraft gasifiers. The gas composition within the combustion zone can be expected to change significantly as partial oxidation of the fuel occurs. As no axial gas concentrations have been reported for downdraft gasifiers, estimates of the gas composition within the combustion zone were based on measured exit gas compositions. In Table 4, the exit gas compositions for various downdraft biomass gasifiers are listed.

While oxygen is not present in the exit gas, it will be present in the combustion zone. From the experimental data of Zainal et al.,$^{79}$ the oxygen concentration within the combustion zone can be estimated to be $11 \%$. Oxygen may react both in the gas phase and with the biomass char. The fraction reacting in the gas-phase is unknown, but the gas-phase reactions would be expected to be faster than the heterogeneous char $+\mathrm{O}_{2}$ reaction at these temperatures. Even so, for a conservative assessment we assume a low level of $1 \% \mathrm{O}_{2}$, substituting a small fraction of the nitrogen in the average gas composition (Table 4) with oxygen.

The predictions for the conversion of the methyl chloride under these conditions are depicted in Fig. 14. Based on the modeling, it is highly probable that all methyl chloride is consumed within the combustion zone as the time for full conversion is below $6 \mathrm{~ms}$ for all temperatures above $1373 \mathrm{~K}$. The consumption rate of methyl chloride increases significantly when small amounts of oxygen is present. This is expected as the presence of oxygen promotes the formation of

Table 4 Exit gas composition from downdraft biomass gasifiers. The gas composition is given on a dry basis in vol\%

\begin{tabular}{lllllll}
\hline $\mathrm{H}_{2}$ & $\mathrm{CO}$ & $\mathrm{CO}_{2}$ & $\mathrm{CH}_{4}$ & $\mathrm{H}_{2} \mathrm{O}$ & $\mathrm{N}_{2}$ & Source \\
\hline 17 & 21 & 13 & 1 & - & 48 & 72 \\
31 & 20 & 15 & 1.2 & - & 33 & 71 \\
14 & 24 & 15 & 2.0 & - & 45 & 79 \\
18 & 18 & 11 & 1.2 & - & 51 & 64 \\
20 & 21 & 14 & 1.4 & - & 45 & Average
\end{tabular}




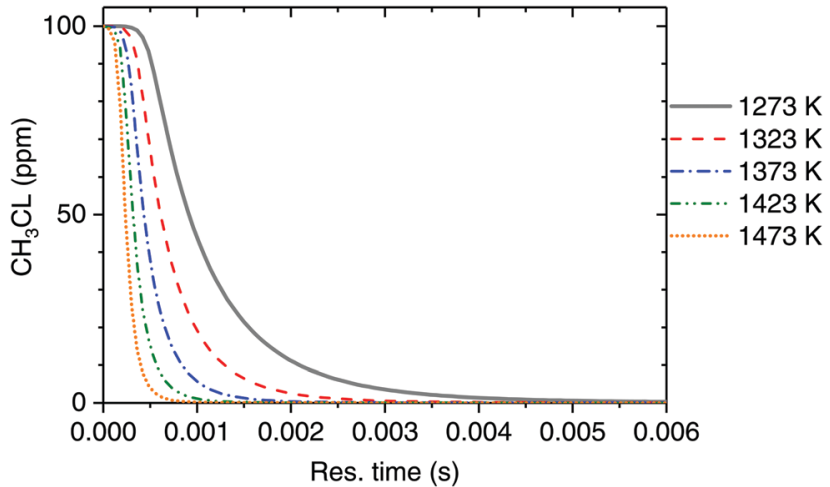

Fig. 14 Thermal conversion of methyl chloride within a downdraft gasifier with $1 \%$ of oxygen present. The initial gas composition for the simulation is $20 \% \mathrm{H}_{2}, 21 \% \mathrm{CO}, 14 \% \mathrm{CO}_{2}, 1.4 \% \mathrm{CH}_{4}, 1.0 \% \mathrm{O}_{2}$; balance $\mathrm{N}_{2}$ (see Table 4). The pressure is atmospheric; temperature and residence time as shown in the figure.

radicals. However, even in the absence of $\mathrm{O}_{2}$, the thermal conversion of methyl chloride occurs rapidly; methyl chloride is consumed in less than $200 \mathrm{~ms}$ at $1373 \mathrm{~K}$.

The gas residence time within the combustion zone of a downdraft gasifier is unknown; however, with its fast consumption rate, methyl chloride will be expected to completely deplete in the gasifier.

The presence of oxygen mainly serves to promote chain branching and increase the concentrations of the $\mathrm{O} / \mathrm{H}$ radicals, but the dominant reaction pathways for methyl chloride consumption are similar to those in the absence of oxygen (Fig. 13). This means that the oxidation routes for methyl chloride in the downdraft gasifier are largely the same as in the fluidized bed gasifier, even though the reaction is faster. Most of the methyl chloride is consumed by the reaction with atomic hydrogen to form $\mathrm{CH}_{3}+\mathrm{HCl}(\mathrm{R} 3)$ and $\mathrm{CH}_{2} \mathrm{Cl}+\mathrm{H}_{2}$ (R4). Also reactions of methyl chloride with other radicals, mainly $\mathrm{OH}, \mathrm{CH}_{3}$, and $\mathrm{O}$, contribute to a minor extent at lower temperatures.

\section{Entrained bed gasifier}

The entrained bed gasifier operates at high temperatures of $1573-1773 \mathrm{~K}^{71,80}$ and with gas residence times of a few seconds. ${ }^{81}$ Since the thermal conversion of methyl chloride, even in the absence of oxygen (Fig. 4), occurs very rapidly at high temperature, it can be expected that all the methyl chloride that is formed within an entrained bed gasifier will be completely decomposed due to the high operating temperatures.

\section{Measures for control of methyl chloride}

Based on our analysis, we conclude that all the methyl chloride formed within downdraft and entrained-bed gasifiers will be decomposed in situ into hydrogen chloride due to the high temperatures within these two types of gasifiers. However, for circulating and bubbling fluidized bed gasifiers emission of methyl chloride with the product gas is a concern, particularly if the gasifier is operated at lower temperatures.

If the methyl chloride content of the product gas is too high, either pre-processing of the fuel or downstream measures will be required. The current trend in chlorine removal favors high-temperature, dry gas cleaning using solid sorbents, in particular calcium and sodium carbonates. ${ }^{6}$ There are only limited data available for removal of $\mathrm{CH}_{3} \mathrm{Cl}$ by sodium carbonate ${ }^{82}$ and no reports on the efficiency of calcium species. However, neither technology can be expected to be effective in capturing $\mathrm{CH}_{3} \mathrm{Cl}$.

Alternatives such as thermal processing of the gas (with or without addition of oxygen/air) or catalytic cleaning are technically possible but may not be economically feasible. Removal of methyl chloride by catalytic steam reforming has been investigated, ${ }^{83,84}$ but this would be costly.

Pre-treatment of the biomass is possibly an alternative to downstream cleaning. In torrefaction, which is a mild form of pyrolysis typically conducted at temperatures of 523-593 $\mathrm{K}$ in an inert atmosphere, ${ }^{11}$ the biomass is upgraded to a high quality fuel. The gas released from the torrefaction process can be combusted and used to supply the energy needed for the torrefaction process. Saleh et al. ${ }^{11}$ reported that $20 \%$ of the chlorine in straw was released at a temperature of $523 \mathrm{~K}$ and at $623 \mathrm{~K}$ the release of chlorine was increased to $64 \%$. For woody biomass, almost all the chlorine was released at $623 \mathrm{~K}$. Saleh et al. found that the majority of the chlorine released appeared as methyl chloride. However, other volatiles will also be released during the thermal pretreatment, reducing the amount of gas produced from the gasifier and possibly decreasing the efficiency of the plant.

\section{Conclusions}

A chemical kinetic model for thermal conversion of methyl chloride under conditions relevant for gasification was established, supported by $a b$ initio calculations for the reactions $\mathrm{CH}_{2} \mathrm{Cl}+\mathrm{O}_{2}$ and $\mathrm{CH}_{2} \mathrm{Cl}+\mathrm{C}_{2} \mathrm{H}_{4}$. The model predicted the decomposition and oxidation of methyl chloride with satisfactory results. Under gasification conditions where $\mathrm{CH}_{3} \mathrm{Cl}$ is present in trace quantities, its decomposition involves only a few reactions. Methyl chloride is consumed by thermal dissociation, $\mathrm{CH}_{3} \mathrm{Cl}(+\mathrm{M}) \rightarrow \mathrm{CH}_{3}+\mathrm{Cl}(+\mathrm{M})$, and by reaction with atomic hydrogen, $\mathrm{CH}_{3} \mathrm{Cl}+\mathrm{H} \rightarrow \mathrm{CH}_{3}+\mathrm{HCl}$. The $\mathrm{Cl}$ atom is converted to $\mathrm{HCl}$ by abstracting $\mathrm{H}$ from $\mathrm{H}_{2}, \mathrm{CH}_{4}$, or $\mathrm{C}_{2} \mathrm{H}_{4}$ from the gasification gas. Any $\mathrm{CH}_{2} \mathrm{Cl}$ formed is recycled to $\mathrm{CH}_{3} \mathrm{Cl}$ by reaction with $\mathrm{C}_{2} \mathrm{H}_{4}$, and formation of higher chlorinated hydrocarbons is predicted to be negligible. Consequently, all methyl chloride that is consumed yields hydrogen chloride under gasification conditions.

For downdraft and entrained-bed gasifiers, calculations show that any methyl chloride formed within the gasifier will be rapidly oxidized to hydrogen chloride and thus methyl chloride is not expected to be present in the exit gas from these two gasification technologies. However, for circulating and bubbling fluidized bed gasifiers emission of methyl chloride with the product gas will be a concern, particularly if the gasifier is operated at lower temperatures.

\section{Conflicts of interest}

There are no conflicts to declare. 


\section{Acknowledgements}

PM thanks the NSF (grant CHE-1531468) for the purchase of computer facilities. The work was supported by DONG Energy, Vattenfall, and the Technical University of Denmark.

\section{References}

1 A. V. Bridgwater, Chem. Eng. J., 2003, 91, 87-102.

2 M. Asadullah, Renewable Sustainable Energy Rev., 2014, 40, 118-132.

3 P. McKendry, Bioresour. Technol., 2002, 83, 37-46.

4 D. J. Stevens, Hot Gas Conditioning: Recent Progress with Larger-Scale Biomass Gasification Systems; Update and Summary of Recent Progress, National Renewable Energy Lab., Golden, CO (US), 2001.

5 P. J. Woolcock and R. C. Brown, Biomass Bioenergy, 2013, 52, 54-84.

6 M. D. Dolan, A. Y. Ilyushechkin, K. G. McLennan and S. D. Sharma, Asia-Pac. J. Chem. Eng., 2012, 7, 171-181.

7 M. P. Kohn, M. J. Castaldi and R. J. Farrauto, Appl. Catal., B, 2014, 144, 353-361.

8 W. Torres, S. S. Pansare and J. G. Goodwin Jr., Catal. Rev.: Sci. Eng., 2007, 49, 407-456.

9 P. Glarborg, Proc. Combust. Inst., 2007, 31, 77-98.

10 V. Narayan, P. A. Jensen, U. B. Henriksen, H. Egsgaard, R. G. Nielsen and P. Glarborg, Energy Fuels, 2016, 30, 1050-1061.

11 S. B. Saleh, J. P. Flensborg, T. K. Shoulaifar, Z. Sárossy, B. B. Hansen, H. Egsgaard, N. DeMartini, P. A. Jensen, P. Glarborg and K. Dam-Johansen, Energy Fuels, 2014, 28, 3738-3746.

12 Y. Wang, H. Wu, Z. Sárossy, C. Dong and P. Glarborg, Fuel, 2017, 197, 422-432.

13 W. Ho, Q.-R. Yu and J. W. Bozzelli, Combust. Sci. Technol., 1992, 85, 23-63.

14 S. L. Hung and L. D. Pfefferle, Combust. Sci. Technol., 1993, 87, 91-107.

15 J. F. Roesler, R. A. Yetter and F. L. Dryer, Combust. Sci. Technol., 1994, 101, 199-229.

16 Y.-P. $\mathrm{Wu}$ and Y.-S. Won, Combust. Flame, 2000, 122, 312-326.

17 D. L. Miller, D. W. Senser, V. A. Cundy and R. A. Matula, Hazard. Waste Hazard. Mater., 1984, 1, 1-18.

18 G. S. Sin, G. S. Park and G. Y. Kim, Bull. Korean Chem. Soc., 2001, 22, 330-332.

19 S. S. Shin, E. V. Vega and K. Y. Lee, Combust., Explos. Shock Waves, 2006, 42, 715-722.

20 J. C. Shi, W. Ye, B. X. Bie, X. J. Long, R. T. Zhang, X. J. Wu and S. N. Luo, Energy Fuels, 2016, 30, 8711-8719.

21 J. Burgoyne, C. Cullis and M. Lieberman, Symp. (Int.) Combust., [Proc.], 1969, 12, 943-955.

22 H. Valeiras, A. K. Gupta and S. M. Senkan, Combust. Sci. Technol., 1984, 36, 123-133.

23 S. B. Karra and S. M. Senkan, Combust. Sci. Technol., 1987, 54, 333-347.
24 H. K. Chelliah, G. Yu, T. O. Hahn and C. K. Law, Symp. (Int.) Combust., [Proc.], 1992, 24, 1083-1090.

25 L. Wang, P. Jalvy and R. Barat, Combust. Sci. Technol., 1994, 97, 13-36.

26 J. W. Huang, I. Onal and S. M. Senkan, Environ. Sci. Technol., 1997, 31, 1372-1381.

27 J. C. Leylegian, Combust. Flame, 2008, 152, 144-153.

28 A. Ranzi, M. Dente, M. Rovaglio, T. Faravelli and S. Karra, Chem. Eng. Commun., 1992, 117, 17-39.

29 W.-P. Ho, R. B. Barat and J. W. Bozzelli, Combust. Flame, 1992, 88, 265-295.

30 G. P. Miller, V. A. Cundy, T. W. Lester and J. W. Bozzelli, Combust. Sci. Technol., 1994, 98, 123-136.

31 W. Ho, M. R. Booty, R. S. Magee and J. W. Bozzelli, Ind. Eng. Chem. Res., 1995, 34, 4185-4192.

32 H. Wang, T. O. Hahn, C. J. Sung and C. K. Law, Combust. Flame, 1996, 105, 291-307.

33 J. C. Leylegian, D. L. Zhu, C. K. Law and H. Wang, Combust. Flame, 1998, 114, 285-293.

34 C. Procaccini, J. W. Bozzelli, J. P. Longwell, K. A. Smith and A. F. Sarofim, Environ. Sci. Technol., 2000, 34, 4565-4570.

35 Y. P. Wu and Y. S. Won, J. Ind. Eng. Chem., 2003, 9, 775-786.

36 M. Weissman and S. Benson, J. Phys. Chem., 1983, 87, 243-244.

37 J. K. Parker, W. A. Payne, R. J. Cody, F. L. Nesbitt, L. J. Stief, S. J. Klippenstein and L. B. Harding, J. Phys. Chem. A, 2007, 111, 1015-1023.

38 A. W. Jasper, S. J. Klippenstein and L. B. Harding, J. Phys. Chem. A, 2010, 114, 5759-5768.

39 P. B. Roussel, P. D. Lightfoot, F. Caralp, V. Catoire, R. Lesclaux and W. Forst, J. Chem. Soc., Faraday Trans., 1991, 87, 2367-2377.

40 T. Ko, A. Fontijn, K. Lim and J. Michael, Symp. (Int.) Combust., [Proc.], 1992, 24, 735-742.

41 P. H. Taylor, Z. Jiang and B. Dellinger, Int. J. Chem. Kinet., 1993, 25, 9-23.

42 F. Fenter, P. Lightfoot, F. Caralp, R. Lesclaux, J. Niiranen and D. Gutman, J. Phys. Chem., 1993, 97, 4695-4703.

43 M. G. Bryukov, I. R. Slagle and V. D. Knyazev, J. Phys. Chem. A, 2001, 105, 3107-3122.

44 A. A. Shestov, K. V. Popov and V. D. Knyazev, J. Phys. Chem. A, 2005, 109, 6249-6254.

45 H. Hashemi, J. M. Christensen, S. Gersen, H. Levinsky, S. J. Klippenstein and P. Glarborg, Combust. Flame, 2016, 172, 349-364.

46 M. Pelucchi, A. Frassoldati, T. Faravelli, B. Ruscic and P. Glarborg, Combust. Flame, 2015, 162, 2693-2704.

47 J. A. Montgomery, M. J. Frisch, J. W. Ochterski and G. A. Petersson, J. Chem. Phys., 1999, 110, 2822-2827.

48 R. Zhu, C.-C. Hsu and M. Lin, J. Chem. Phys., 2001, 115, 195-203.

49 P. L. Fast, M. L. Sanchez and D. G. Truhlar, Chem. Phys. Lett., 1999, 306, 407-410.

50 E. C. Barnes, G. A. Petersson, J. Montgomery, M. J. Frisch and J. M. L. Martin, J. Chem. Theory Comput., 2009, 5, 2687-2693. 
51 M. J. Frisch, G. W. Trucks, H. B. Schlegel, G. E. Scuseria, M. A. Robb, J. R. Cheeseman, G. Scalmani, V. Barone, G. A. Petersson, H. Nakatsuji, et al., Gaussian16 (rev. A.03), Gaussian, Wallingford, CT, 2016.

52 M. Schwartz, L. R. Peebles, R. J. Berry and P. Marshall, J. Chem. Phys., 2003, 118, 557-564.

53 K. Macken and H. Sidebottom, Int. J. Chem. Kinet., 1979, 11, 511.

54 M. G. Bryukov, I. R. Slagle and V. D. Knyazev, J. Phys. Chem. A, 2002, 106, 10532-10542.

55 S. S. Abadzhev, I. P. Dzikh and V. U. Shevchuk, Kinet. Catal., 1989, 30, 893-897.

56 K. P. Lim and J. V. Michael, J. Chem. Phys., 1993, 98, 3919-3928.

57 S. Ramazani, J. Chem. Phys., 2013, 138, 194305.

58 Chemkin-PRO, version 18.0; ANSYS, 2017.

59 A. Cuoci, A. Frassoldati, E. Ranzi and T. Faravelli, Comput. Phys. Commun., 2015, 192, 237-264.

60 R. Kee, M. Coltrin, P. Glarborg and H. Zhu, Chemically Reacting Flow Theory, Modeling and Simulation, Wiley, US, 2nd edn, 2017.

61 B. McBride and S. Gordon, Computer Program for Calculating and Fitting Thermodynamic Functions, NASA RP-1271, 1992.

62 B. Kaesche-Krischer, Chem. Ing. Tech., 1963, 35, 856-860.

63 A. Kumar, D. D. Jones and M. A. Hanna, Energies, 2009, 2, 556-581.

64 C.-L. Hsi, T.-Y. Wang, C.-H. Tsai, C.-Y. Chang, C.-H. Liu, Y.C. Chang and J.-T. Kuo, Energy Fuels, 2008, 22, 4196-4205.

65 D. Ross, R. Noda, M. Horio, A. Kosminski, P. Ashman and P. Mullinger, Fuel, 2007, 86, 1417-1429.

66 Y. Sailaukhanuly, Z. Sárossy, L. Carlsen and H. Egsgaard, Chemosphere, 2014, 111, 575-579.

67 S. R. A. Kersten, W. Prins, A. Van der Drift and W. P. M. Van Swaaij, Ind. Eng. Chem. Res., 2003, 42, 6755-6764.

68 P. Garca-Ibanez, A. Cabanillas and J. Sánchez, Biomass Bioenergy, 2004, 27, 183-194.
69 H. Boerrigter, H. Den Uil and H.-P. Calis, Green diesel from biomass via Fischer-Tropsch synthesis: new insights in gas cleaning and process design; Pyrolysis and gasification of biomass and waste, CPL Press, Newbury, UK, 2003.

70 H. Boerrigter, H. Den Uil and H.-P. Calis, Benchmarking biomass gasification technologies for fuels, chemicals and hydrogen production, US Department of Energy. National Energy Technology Laboratory, 2002.

71 K. Broer, P. J. Woolcock, P. A. Johnston and R. C. Brown, Fuel, 2015, 140, 282-292.

72 A. Bridgwater, Fuel, 1995, 74, 631-653.

73 J. Gil, J. Corella, M. P. Aznar and M. A. Caballero, Biomass Bioenergy, 1999, 17, 389-403.

74 A. Gómez-Barea, R. Arjona and P. Ollero, Energy Fuels, 2005, 19, 598-605.

75 A. Gomez-Barea and B. Leckner, Prog. Energy Combust. Sci., 2010, 36, 444-509.

76 Y. D. Kim, C. W. Yang, B. J. Kim, K. S. Kim, J. W. Lee, J. H. Moon, W. Yang, U. Y. Tae and U. Do Lee, Appl. Energy, 2013, 112, 414-420.

77 I. Narvaez, A. Orio, M. P. Aznar and J. Corella, Ind. Eng. Chem. Res., 1996, 35, 2110-2120.

78 J. Corella, J. M. Toledo and R. Padilla, Energy Fuels, 2004, 18, 713-720.

79 Z. A. Zainal, A. Rifau, G. A. Quadir and K. N. Seetharamu, Biomass Bioenergy, 2002, 23, 283-289.

80 A. Molino, S. Chianese and D. Musmarra, J. Energy Chem., 2016, 25, 10-25.

81 K. Qin, W. Lin, S. Fæster, P. A. Jensen, H. Wu and A. D. Jensen, Energy Fuels, 2012, 27, 262-270.

82 V. Zamansky, G. Kryder and W. Seeker, Symp. (Int.) Combust., [Proc.], 1992, 24, 735-742.

83 K. Intarajang and J. T. Richardson, Appl. Catal., B, 1999, 22, 27-34.

84 J. D. Ortego, J. T. Richardson and M. V. Twigg, Appl. Catal., B, 1997, 12, 339-355. 